\title{
PENGARUH PENERAPAN MODEL PEMBELAJARAN KOOPERATIF TIPE TEAM ASSISTED INDIVIDUALIZATION (TAI) TERHADAP HASIL BELAJAR SISWA PADA POKOK BAHASAN STRUKTUR TUMBUHAN KELAS VIII DI SMP HANG KASTURI BATAM TAHUN PELAJARAN 2013/2014.
}

\author{
Dahrul Aman Harahap \\ Dosen Tetap Pendidikan Biologi FKIP Universitas Riau Kepulauan Batam
}

\begin{abstract}
ABSTRAK
DAHRUL AMAN HARAHAP. Pengaruh Penerapan Model Pembelajaran Kooperatif Tipe Team Assisted Individualization (TAI) Terhadap Hasil Belajar Siswa pada Pokok Bahasan Struktur Tumbuhan Kelas VIII di SMP Hang Kasturi Batam Tahun Pelajaran 2013/2014.

Penelitian yang dilakukan di SMP Hang Kasturi Batam dari bulan April sampai Bulan Juni Tahun 2014 bertujuan untuk mengetahui Pengaruh Penerapan Model Pembelajaran Kooperatif Tipe Team Assisted Individualization (TAI) Terhadap Hasil Belajar Siswa pada Pokok Bahasan Struktur Tumbuhan Kelas VIII di SMP Hang Kasturi Batam. Penelitian ini merupakan penelitian eksperimen menggunakan populasi seluruh siswa kelas VIII dimana sampel penelitian yaitu kelas VIIIC $_{C}$ sebagai kelas kontrol dan kelas VII $_{B}$ sebagai kelas eksperimen dengan teknik pengambilan sampel acak sederhana (Simple random Sampling)
\end{abstract}

Data penelitian adalah hasil belajar Siswa kelas VIII yang mengikuti proses pembelajaran sistem dalam kehidupan tumbuhan. Adapun yang menjadi variabel bebas adalah (X) yaitu pemberian model Team Assisted Individualization dan varibel $(\mathrm{Y})$ yaitu hasil belajar siswa. Data penelitian diperoleh menggunakan tes hasil belajar berupa tes objektif pilihan ganda yang dilaksanakan setelah keseluruhan proses pembelajaran berlangsung.

Analisis data dilakukan dengan menggunakan teknik statistik deskriftif dan teknik statistik inferensial. Analisis deskriptif dilakukan untuk menyajikan data setiap kelompok perlakuan dengan uji t (t-test) pada taraf signifikansi $\alpha=0.05$. maka di dapat thitung $3.299>t_{\text {tabel }} 2.002$ yang berarti hipotesis yang dikemukakan diterima yaitu model Team Asssted Individualization berpengaruh nyata terhadap hasil belajar biologi siswa kelas VIII SMP Hang Kasturi Batam pada pembelajaran struktur tumbuhan.

Kata kunci $\quad$ : Model Team Assisted Individualization (TAI) dan Hasil Belajar

\section{BAB I. PENDAHULUAN}

\section{Latar Belakang Masalah}

Berdasarkan observasi penulis hasil belajar biologi siswa masih rendah. Nilai rata-rata siswa masih jauh dari Kriteria Ketuntasan Minimal (KKM) yang telah ditetapkan sekolah. KKM untuk mata pelajaran biologi adalah 65 .

Tabel 1. Nilai rata-rata siswa semester ganjil kelas VIII di SMP Hang Kasturi Batam tahun ajaran 2011/2012 


\begin{tabular}{|l|l|l|l|}
\hline No & Kelas & Jumlah Siswa & Nilai rata-rata UAS Biologi \\
\hline 1 & VIII A & 33 Siswa & 60,36 \\
\hline 2 & VIII B & 30 Siswa & 64,2 \\
\hline 3 & VIII C & 30 Siswa & 59,60 \\
\hline
\end{tabular}

Sumber : Guru Biologi Kelas VIII SMP Hang Kasturi Batam

Model pembelajaran kooperatif tipe TAI merupakan model pembelajaran yang membentuk kelompok kecil yang heterogen dengan latar belakang cara berfikir yang berbeda untuk saling membantu terhadap siswa lain yang membutuhkan bantuan. Dalam model ini, diterapkan bimbingan antar teman yaitu siswa yang pandai bertanggung jawab terhadap siswa yang lemah. TAI (Team Assisted Individualization) dapat diterjemahkan sebagai jenis pembelajaran dengan Bantuan Individual Dalam Kelompok (Bidak).

Untuk mencapai hasil belajar yang maksimal dalam penyampain materi sistem dalam kehidupan tumbuhan dibutuhkan suatu model pembelajaran yang akan menunjang pencapaian hasil belajar yang kita inginkan. Maka dari itu dalam pembelajaran ini dipilih model pembelajaran kooperatif tipe Team Assisted Individualization (TAI) untuk mendapatkan hasil belajar yang baik. Metode ini sangat efektif bila diaplikasikan dengan kondisi siswa yang memiliki masalah dalam penilaian yang jauh dari standar Kriteria Ketuntasan Minimal (KKM) yang telah ditetapkan sekolah.

Dengan ini penulis melakukan penelitian terhadap "Pengaruh penerapan model pembelajaran kooperatif tipe Team Assisted Individualization (TAI) terhadap hasil belajar siswa pada pokok bahasan sistem dalam kehidupan tumbuhan kelas VIII di SMP Hang Kasturi Batam Tahun Ajaran 2012/2013".

\section{Identifikasi Masalah}

Berdasarkan latar belakang yang dikemukakan diatas, dapat diidentifikasi beberapa masalah sebagai berikut :

Hasil belajar biologi masih rendah.

Stategi yang digunakan guru biologi belum bervariasi

Kurangnya upaya guru terhadap inovasi pada model pembelajaran

\section{Batasan Masalah}

Adapun batasan dalam penelitian ini adalah, sebagai berikut :

"Model pembelajaran kooperatif tipe Team Assisted Individualization (TAI) atau dibandingkan dengan kelas konvensional terhadap hasil belajar siswa pada pokok bahasan Struktur Tumbuhan kelas VIII di SMP Hang Kasturi Batam Tahun Pelajaran 2013/2014”

\section{Rumusan Masalah}

Berdasarkan dari latar belakang dan batasan masalah diatas,maka rumusan masalah dalam penelitian ini adalah "Apakah berpengaruh pembelajaran tipe Team Assisted Individualization (TAI) dengan kelas konvensional terhadap hasil belajar siswa kelas VIII di SMP Hang Kasturi Batam"

\section{Tujuan Penelitian}

Berdasarkan dari rumusan masalah diatas, maka tujuan penelitian ini adalah "untuk mengetahui pengaruh model pembelajaran tipe Team Assisted Individualization (TAI) dengan kelas konvensional terhadap hasil belajar siswa kelas VIII di SMP Hang Kasturi Batam” 


\section{BAB II METODE PENELITIAN}

\section{Tempat dan Waktu Penelitian}

Penelitian ini di laksanakan di SMP Hang Kasturi Batam bertempat di Tanjung Uma RT 04 RW 01 Kelurahan Tanjung Uma Kecamatan Lubuk Baja Kota Batam pada semester genap tahun pelajaran 2013-2014, waktu penelitian dilaksankan mulai bulan April - Juni 2014.

\section{Metode dan Rancangan Penelitian}

Metode penelitian ini adalah eksperimen semu. Perlakuan yang penulis berikan pada kelas eksperimen adalah menggunakan model pembelajaran Team Assisted Individualization, sedangkan pada kelas kontrol menggunakan pembelajaran konvensional. Rancanagan penelitian yang digunakan adalah Randomized Control Group Posttest Only Design yang terlihat pada tabel 3 dibawah ini.

Tabel 2. : Randomized Control Group Posttest Only Design

\begin{tabular}{|l|l|l|}
\hline Kelas & Perlakuan & Test \\
\hline Eksperimen & $X_{1}$ & T \\
\hline Kontrol & $X_{0}$ & T \\
\hline
\end{tabular}

Keterangan :

$\mathrm{X}$ : penerapan model pembelajaran dengan menggunakan tipe Team Assisted Individualization (TAI)

Y: Hasil belajar siswa pada pokok bahasan sistem dalam kehidupan tumbuhan

$\mathrm{T}$ : tes yang diberikan diakhir pokok bahasan (posttest)

\section{Populasi dan Sampel}

Riduwan (2011) mengatakan bahwa populasi adalah keseluruhan dari karakteristik atau unit hasil pengukuran yang menjadi objek penelitian.

Tabel 3. Populasi penelitian siswa kelas VIII di SMP Hang Kasturi Batam tahun Pelajaran 2012/2013.

\begin{tabular}{|l|l|l|}
\hline No & Kelas & Jumlah siswa \\
\hline 1 & VIII A & 33 \\
\hline 2 & VIII B & 30 \\
\hline 3 & VIII C & 30 \\
\hline
\end{tabular}

(sumber : Guru Biologi Kelas VIII SMP Hang Kasturi Batam)

Sampel penelitian adalah sebagian dari populasi yang diambil sebagai sumber data dan dapat mewakili seluruh populasi. Sampel dalam penelitian ini akan diambil dengan menggunakan teknik random sampling yaitu pengambilan sampel dari anggota populasi dengan menggunakan acak tanpa memperhatikan strata (tingkatan) dalam anggota populasi tersebut dan didapat kelas VIII B sebagai kelas eskperimen dan kelas VIII C sebagai kelas kontrol.

\section{BAB III HASIL PENELITIAN DAN PEMBAHASAN}

\section{Hasil Penelitian}

Pada bagian ini akan di uraikan secara terperinci mengenai hasil dari penelitian tentang pengaruh penerapan metode TAI terhadap hasil belajar siswa. Penelitian ini dilakukan pada dua kelas yaitu kelas VIII B sebagai kelas eksperimen dan kelas VIII C sebagai kelas control.

Sebelum melaksanakan penelitian, terlebih dahulu peneliti melakukan uji coba instrument untuk mendapatkan data validitas dan reliabelitas dengan diketahui nilai validitas dan reliabelitas tersebut, maka instrument dinyatakan layak untuk digunakan dalam mendapatkan data penelitian. Dari 30 butir soal yang diberikan di dapat 20 soal yang valid. Setelah di dapat instrument penelitian yang valid dan reliable, barulah di laksanakan penelitian. 
Tabel 4. Rekapitulasi Analisis Deskriptif Data Hasil Penelitian

\begin{tabular}{|l||l|l|l||l||l||l||l|l|l|l||}
\hline \multirow{2}{*}{$\begin{array}{l}\text { Kelompok } \\
\text { perlakuan }\end{array}$} & \multicolumn{9}{|l||}{ Data Deskriptif sampel penelitian } \\
\cline { 2 - 9 } & $\mathrm{n}$ & $\sum \mathrm{X}$ & $\begin{array}{l}\text { Xma } \\
\mathrm{X}\end{array}$ & $\begin{array}{l}\text { Xmi } \\
\mathrm{n}\end{array}$ & $\mathrm{r}$ & $\mathrm{X}$ & $\mathrm{Mo}$ & $\mathrm{Me}$ & $\mathrm{S}$ & $\mathrm{S} 2$ \\
\hline Kelas $\left(\mathrm{X}_{1}\right)$ & 30 & 2320 & 100 & 50 & 50 & $\begin{array}{l}77.3 \\
3\end{array}$ & 80 & 80 & $\begin{array}{l}12.29 \\
\mathbf{9}\end{array}$ & $\begin{array}{l}151.26 \\
4\end{array}$ \\
\hline Kelas $\left(\mathrm{X}_{0}\right)$ & 30 & 1990 & 90 & 40 & 50 & $\begin{array}{l}66.3 \\
3\end{array}$ & 70 & 70 & 13.51 & $\begin{array}{l}182.64 \\
4\end{array}$ \\
\hline \hline
\end{tabular}

Data yang diperoleh berdasarkan hasil penelitian dengan penerapan metode TAI mempunyai rentang nilai 0-100. Jumlah siswa yang menjadi sampel penelitian ( $\mathrm{n}$ ) sebanyak 30 siswa, total nilai hasil belajar 23.20, nilai terbesar siswa ( $\mathrm{X} \max$ ) adalah 100 dan nilai terkecil (X min) adalah 50 median/ nilai tengah ( $\mathrm{Me}$ ) adalah 80 dan nilai yang paling sering muncul/modus adalah 80 .Data hasil penelitian penerapan pembelajaran metode TAI ditampilkan dalam distribusi frekuensi pada table dibawah ini :

Tabel 5. Distribusi Frekuensi Nilai Hasil Belajar Siswa pada Kelas Metode Pembelajaran Kooperatif tipe $T A I$

\begin{tabular}{|l|l|l|l|l|l|l|}
\hline $\begin{array}{l}\text { No } \\
\text { Kelas }\end{array}$ & Nilai Kelas & $\begin{array}{l}\text { Nilai } \\
\text { Tengah }\end{array}$ & $\begin{array}{l}\text { Batas } \\
\text { Bawah }\end{array}$ & $\begin{array}{l}\text { Batas } \\
\text { Atas }\end{array}$ & Absolut & Relatif \\
\hline 1 & $47-55$ & 51 & 46.5 & 55.5 & 2 & 6.67 \\
\hline 2 & $56-64$ & 60 & 55.5 & 64.5 & 1 & 3.33 \\
\hline 3 & $65-73$ & 69 & 64.5 & 73.5 & 9 & 30 \\
\hline 4 & $74-82$ & 78 & 73.5 & 82.5 & 12 & 40 \\
\hline 5 & $83-91$ & 87 & 82.5 & 91.5 & 3 & 10 \\
\hline 6 & $92-100$ & 96 & 91.5 & 100.5 & 3 & 10 \\
\hline & & & Jumlah & & 30 & 100 \\
\hline
\end{tabular}

Berdasarkan tabel distribusi frekuensi data hasil penelitian kelas eksperimen divisualisasikan ke dalam grafik berbentuk histogram, seperti pada grafik 4.1 berikut. 


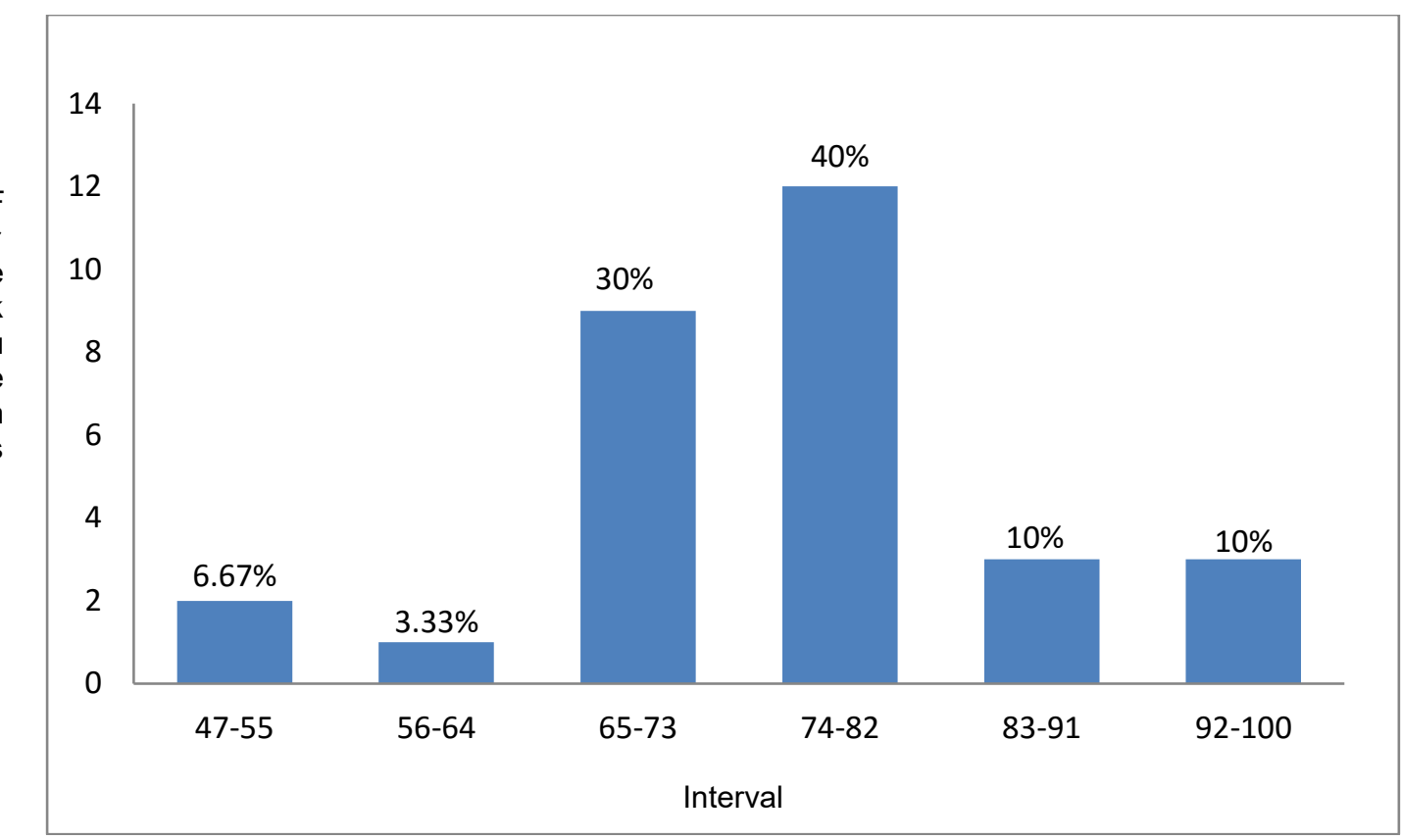

Grafik hasil belajar siswa kelas eksperimen $\left(\mathrm{x}_{1}\right)$

Dalam hal ini, tingginya pencapaian prestasi belajar siswa dimungkinkan karena proses pembelajaran pada kelas eksperimen memberikan kesempatan pada siswa untuk bekerjasama dengan teman-temannya dalam menemukan suatu pengetahuan. Metode pembelajaran kooperatif tipe TAI ini dapat membuat siswa lebih aktif, tidak bergantung kepada guru.

Berdasarkan hasil penelitian yang telah ditabulasi dalam distribusi frekuensi dan divisualisasikan, terlihat bahwa dari 30 orang siswa sampel penelitian kelas eksperimen, pada kisaran pemusatan data dengan rata-rata 77,33 terdapat 27 orang siswa atau $90 \%$ yang mendapat nilai di atas KKM.

Data hasil penelitian metode konvensional ditampilkan dalam distribusi frekuensi pada table dibawah ini :

Tabel 6. Distribusi Frekuensi Nilai Hasil Belajar Siswa pada Kelas Metode Konvensional

\begin{tabular}{|l|l|l|l|l|l|l|}
\hline $\begin{array}{l}\text { No } \\
\text { Kelas }\end{array}$ & Nilai Kelas & $\begin{array}{l}\text { Nilai } \\
\text { Tengah }\end{array}$ & $\begin{array}{l}\text { Batas } \\
\text { Bawah }\end{array}$ & $\begin{array}{l}\text { Batas } \\
\text { Atas }\end{array}$ & Absolut & Relatif \\
\hline 1 & $37-45$ & 41 & 36.5 & 45.5 & 3 & 10 \\
\hline 2 & $46-54$ & 50 & 45.5 & 54.5 & 2 & 6.67 \\
\hline 3 & $55-63$ & 59 & 54.5 & 63.5 & 7 & 23.3 \\
\hline 4 & $64-72$ & 68 & 63.5 & 72.5 & 12 & 40 \\
\hline 5 & $73-81$ & 77 & 72.5 & 81.5 & 3 & 10 \\
\hline 6 & $82-90$ & 86 & 81.5 & 90.5 & 3 & 10 \\
\hline & & & Jumlah & & 30 & 100 \\
\hline
\end{tabular}

Berdasarkan tabel distribusi frekuensi data hasil penelitian kelas eksperimen divisualisasikan ke dalam grafik berbentuk histogram, seperti pada grafik 4.2 berikut: 


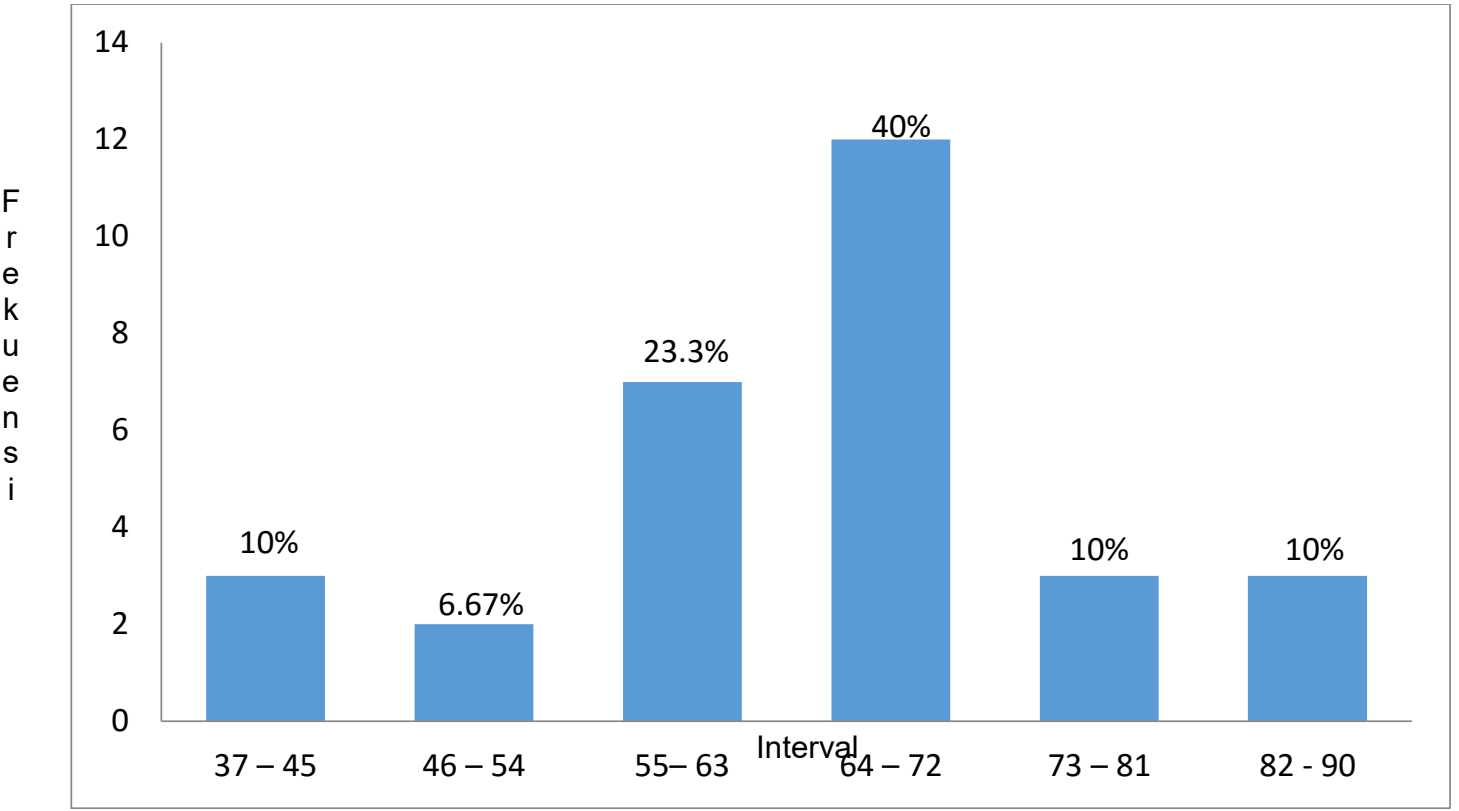

Grafik hasil belajar siswa kelas kontrol $\left(\mathrm{x}_{0}\right)$

Berdasarkan penelitian yang telah di tabulasi dalam distibusi frekuensi dan divisualisasikan, terlihat bahwa dari 30 orang siswa sampel penelitian pada kelas kontrol, pada kisaran pemusatan data (rerata) 66.33 tidak terdapat siswa yang mendapat nilai sempurna dan terdapat 12 orang siswa atau $39.97 \%$ di bawah rata-rata.

\section{Teknik Analisis Data}

\section{Uji normalitas}

Uji normalitas dilakukan untuk melihat normal tidaknya sebaran data yang dianalisis dari setiap kelompok perlakuan penelitian. Suatu penelitian yang akan melakukan uji hipotesis harus memiliki sebaran data berdistribusi normal. Uji normalitas dilakukan dengan menggunakan chi kuadrat dengan taraf signifikan $\alpha=0,05$. Dengan kriteria t-hitung $<\mathrm{r}$-tabel yang berarti data berditribusi normal, sedangkan t-hitung $>\mathrm{t}$-tabel yang berarti data tidak berdistribusi normal. Hasil pengujian normalitas data pada kelas eksperimen dan kelas kontrol dapat dilihat pada tabel dibawah ini :

\section{Tabel 7. Rekapitulasi hasil perhitungan Uji Normalitas}

\begin{tabular}{|l|l|l|l|l|}
\hline Kelas & Jumlah Sampel & t-hitung & t-tabel & Kesimpulan \\
\hline $\begin{array}{l}\text { Kelas } \\
\text { Eksperimen }\end{array}$ & 30 & 8.00 & 11.070 & Normal \\
\hline Kelas Kontrol & 30 & 10.55 & 11.070 & Normal \\
\hline
\end{tabular}

Berdasarkan hasil perhitungan uji normalitas di atas, berarti data dari kedua kelas berdistribusi normal dan uji dapat dilanjutkan untuk melihat homogenitas asal populasi kelompok data.

\section{Uji Homogenitas}

Uji homogenitas dilakukan dengan membandingkn nilai varians data dari kedua kelas penelitian. Rekapitulasi hasil perhitungan uji homogenitas dapat dilihat pada tabel dibawah ini

Tabel 8. Rekapitulasi Perhitungan Uji Homogenitas

\begin{tabular}{|c|c|c|c|c|}
\hline Kelas & Varians & f-hitung & f-tabel & Kesimpulan \\
\hline eksperimen & 151.264 & & & \\
\hline Control & 182.644 & & & \\
\hline
\end{tabular}


Dari hasil perhitungan uji persyaratan data di atas, maka dapat disimpulkan bahwa data penelitian dinyatakan normal dan homogen sehingga telah memenuhi syarat untuk dilakukan penelitian hipotesis.

\section{Uji Hipotesis}

Pengujian hipotesis dilakukan untuk melihat adanya pengaruh perlakuan kedua kelas penelitian. Pengujian hipotesis dilakukan menggunakan uji t pada taraf signifikansi $\alpha$ 0,05 uji t merupakan teknik analisis inferensial untuk menguji hipotesis dengan melakukan analisis perbandingan rerata antar kedua kelas penelitian untuk membuktikan bahwa kelas yang satu lebih baik dari kelas yang lainnya.

Tabel 4.6 Rekapitulasi hasil perhitungan uji t

\begin{tabular}{|l|l|l|l|l|l|}
\hline PERLAKUAN & $\begin{array}{l}\text { Jumlah } \\
\text { Sampel }\end{array}$ & $\mathrm{Dk}$ & $\mathrm{t}$ hitung & $\mathrm{t}$ tabel & KEPUTUSAN \\
\hline Ekperimen & 30 & 29 & 3.299 & $\alpha=0.05=2.002$ & Tolak $\mathrm{H}_{0}$ \\
\hline Kontrol & 30 & 29 & & $\alpha=0.05=2.002$ & Tolak $\mathrm{H}_{0}$ \\
\hline
\end{tabular}

Berdasarkan hasil perhitungan uji beda menggunakan uji t diperoleh nilai $\mathrm{t}$ hitung dari perbandingan rerata antar kelompok perlakuan sebesar 3.229 sedangkan nilai t tabel pada taraf signifikan $(\alpha=0.05)$ dengan jumlah sampel untuk setiap kelompok perlakuan (n) sebanyak 30 siswa adalah sebesar 2.002 karena nilai thitung lebih besar dari nilai t tabel maka pengujian menolak hipotesis nol $\left(\mathrm{H}_{0}\right)$, yaitu tidak terdapat pengaruh hasil belajar siswa dengan menggunakan metode TAI. Hasil penelitian menerima hipotesis yang diajukan $\left(\mathrm{H}_{\mathrm{i}}\right)$ yaitu terdapat pengaruh hasil belajar siswa dengan menggunakan metode TAI.

Hasil penelitian membuktikan bahwa siswa yng diberi pembelajaran dengan menggunakan metode TAI memungkinkan prestasi belajar lebih baik dibandingkan dengan pembelajaran metode konvensional, dan dapat disimpulkan bahwa pembelajaran sistem dalam kehidupan tumbuhan dengan menggunakan metode TAI lebih cocok dan sesuai untuk pencapaian hasil yang memang sudah ditentukan dibandingkan dengan metode konvensional.

\section{Pembahasan}

Dari hasil yang diperoleh menunjukan bahwa model pembelajaran kooperatif tipe TAI memberikan dampak positif terhadap hasil belajar siswa. Dari penelitian yang dilakukan serta analisis data yang dilakukan, didapat nalai rata-rata kelas eksperimen 77.33 sedangkan kelas kontrol dengan nilai rat-rata 66.33. Serta persentase kelulusan pada kelas eskperimen sebesar 90\% sebanyak 27 siswa, sedangkan pada kelas kontrol 60\% sebanyak 18 siswa. Hal ini juga didukung dengan perhitungan uji-t yaitu diketahui $t_{\text {hitung }}>t_{\text {tabel }}(3.299>2.002)$. Uji hipotesis tersebut menunjukan terdapat pengaruh yang signifikan setelah diterapkan metode pembelajaran kooperatif tipe $T A I$ pada kelas eksperimen materi sistem dalam kehidupan tumbuhan, sehingga hipotesis yang diterima adalah $\mathrm{H}_{\mathrm{I}}$ dan ditolak adalah $\mathrm{H}_{0}$.

Pada dasarnya penerapan model pembelajaran merupakan salah satu aspek penting yang dapat mempengaruhi hasil belajar siswa, model pembelajaran kooperatif merupakan salah satu model yang tepat untuk meningkatkan hasil belajar dan model pembelajaran ini juga dapat meningkatkan sikap tolong menolong dalam berprilaku, hal ini sesuai dengan teori Isjoni (2009) menyatakan pembelajaran kooperatif dapat meningkatkan belajar siswa lebih baik dan meningkatkan sikap tolong menolong dalam perilaku sosial.

Peningkatan dan perkembangan hasil belajar siswa melalui model pembelajaran Team Assisted Individualization (TAI) menjadikan siswa melakukan perubahan pada sikap maupun pengetahuan, karena metode TAI menuntut siswa untuk dapat memahami materi yang 
diajarkan, hal ini sesuai dengan teori Hamalik (2005) Hasil belajar tampak sebagai terjadinya perubahan tingkah laku pada diri siswa, yang dapat diamati dan diukur dalam perubahan pengetahuan sikap dan keterampilan. Perubahan dapat diartikan terjadinya peningkatan dan pengembangan yang lebih baik dibandingkan dengan sebelumnya, misalnya dari tidak tahu menjadi tahu, sikap tidak sopan menjadi sopan dan sebagainya.

Model pembelajaran TAI ini juga dapat menjadikan siswa memahami materi yang dipelajari dalam menjalankan diskusi. Model ini juga mengkombinasikan antara pembelajaran kelompok dan individu, hal ini sangat mendukung dalam pemahaman peserta didik terhadap materi, baik secara individu maupun kelompok, dan bertanggung jawab terhadap soal dan jawaban yang diberikan. Hal ini sesuai dengan teori Slavin (2005) mengemukakan tipe ini mengkombinasikan keunggulan pembelajaran kooperatif dan pembelajaran individual, tipe ini dirancang untuk mengatasi kesulitan belajar siswa secara individual. Oleh karena itu kegiatan pembelajarannya lebih banyak digunakan untuk pemecahan masalah, ciri khas pada model pembelajaran $T A I$ ini adalah setiap siswa secara individual belajar materi pembelajaran yang sudah dipersiapkan oleh guru. Hasil belajar individual dibawa ke kelompok-kelompok untuk di diskusikan dan saling dibahas oleh anggota kelompok, dan semua anggota kelompok bertanggung jawab atas keseluruhan jawaban sebagai tanggung jawab bersama.

Berdasarkan penelitian diperoleh fakta bahwa dalam proses pembelajaran penggunaan model pembelajaran Team Assisted Individualization (TAI) ini dapat dikatakan efektif karena pada saat proses belajar mengajar peserta didik aktif dalam pembelajarannya, hasil belajar lebih baik, hal ini dapat dilihat dari kemampuan siswa dalam menyelesaikan soal pada pokok bahasan sistem dalam kehidupan tumbuhan sehingga kemampuan siswa dapat meningkat.

Hasil penelitian ini juga menunjukan bahwa pembelajaran pada kelas eksperimen lebih baik bila dibandingkan dengan kelas kontrol, karena pada kelas eksperimen siswa bekerja sama yang baik dalam suatu kelompok yang sudah dibentuk, siswa yang pintar dapat membantu siswa yang lemah, sehingga dapat menumbuhkan motivasi dalam pengembangan dan penyelesaian soal pada pokok bahasan sistem dalam kehidupan tumbuhan, dan dengan waktu yang sedikit peserta didik dapat menguasi materi yang sedang dipelajari, melatih siswa bersosialisasi dengan temannya karena dalam model pembelajaran ini pembentukan kelompoknya bersifat heterogen.

Berdasarkan deskripsi data di atas, dapat ditarik kesimpulan bahwa penggunaan model pembelajaran Team Assisted Individualization (TAI) lebih baik bila dibandingkan dengan model pembelajaran konvensional dalam meningkatkan hasil belajar siswa pada pokok bahasan sistem dalam kehidupan tumbuhan.

\section{BAB IV KESIMPULAN DAN SARAN \\ 11. Kesimpulan}

Adapun kesimpulan dari penelitian ini adalah sebagai berikut, yaitu :

1. Pembelajaran dengan menggunakan metode $T A I$ memilki ketuntasan belajar lebih baik dibandingkan metode konvensional, yaitu nilai rata-rata 77.33 dengan persentase kelulusan $90 \%$, sedangkan metode konvensioanal dengan adalah nilai rata-rata 66.33 dengan persentase kelulusan $60 \%$.

2. Terdapat pengaruh model pembelajaran kooperatif tipe Team Assisted Individualization secara positif dan significant terhadap hasil belajar siswa kelas VIII di SMP Hang Kasturi Batam pada pokok bahasan Struktur Tumbuhan Tahun Pelajaran 2014/2015. Hal ini juga dapat terlihat dari nilai thitung 3.229 dan tabel 2.002 .

\section{Saran}


Adapun saran dalam penelitian ini adalah disarankan kepada penelitian lain untuk mengadakan penelitian lanjutan dengan melibatkan variabel yang lebih bervariasi, jumlah sampel dan populasi yang lebih besar, materi yang lebih luas, dan waktu penelitian yang lebih lama.

\section{DAFTAR PUSTAKA}

Arsyad, Azhar. 2010. Media Pembelajaran. Jakarata: PT Rajagrafindo.

Hamalik, Oemar. 2005. Proses Belajar dan Mengajar. Bandung: Sinar Baru Algasindo

Isjoni. 2009. Cooperative Learning. Bandung: Alfabeta

Riduwan. 2011. Dasar-dasar Statistika. Bandung: Tarsito

Slavin, Robert. E. 2005. Cooperative Learning: Theory, research and Pratice. London: Allymand Bacon.

Sugiyono. 2011. Statistika Untuk Penelitian. Bandung: Alfabeta 